CONTRIBUTIONS FROM THE MUSEUM OF THE AMERICAN INDIAN FEYE FOUNDATION Volume V, No. 3

\title{
CERTAIN MOUNDS IN HAYWOOD COUNTY, NORTH CAROLINA
}

BY

GEORGE G. HEYE 



CONTRIBUTIONS FROM THE

MUSEUM OF THE AMERICAN INDIAN

HEYE FOUNDATION

Volume V, No. 3

\title{
CERTAIN MOUNDS IN HAYWOOD COUNTY, NORTH CAROLINA
}

\author{
BY \\ GEORGE G. HEYE
}

(Reprinted from the Holmes ANNIVERSARY VolUME, Washington, I916)

NEW YORK

MUSEUM OF THE AMERICAN INDIAN

HEYE FOUNDATION

1919 


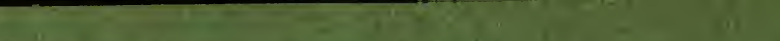


CONTRIBUTIONS FROM THE

MUSEUM OF THE AMERICAN INDIAN

HEYE FOUNDATION

Volume V, No. 3

\section{CERTAIN MOUNDS IN HAYWOOD COUNTY, NORTH CAROLINA}

BY

GEORGE G. HEYE

NEW YORK

MUSEUM OF THE AMERICAN INDIAN

HEYE FOUNDATION

I919 
PRESS OF
THE NEW ERA PRINTING COMPANY LANCASTER, PA. 



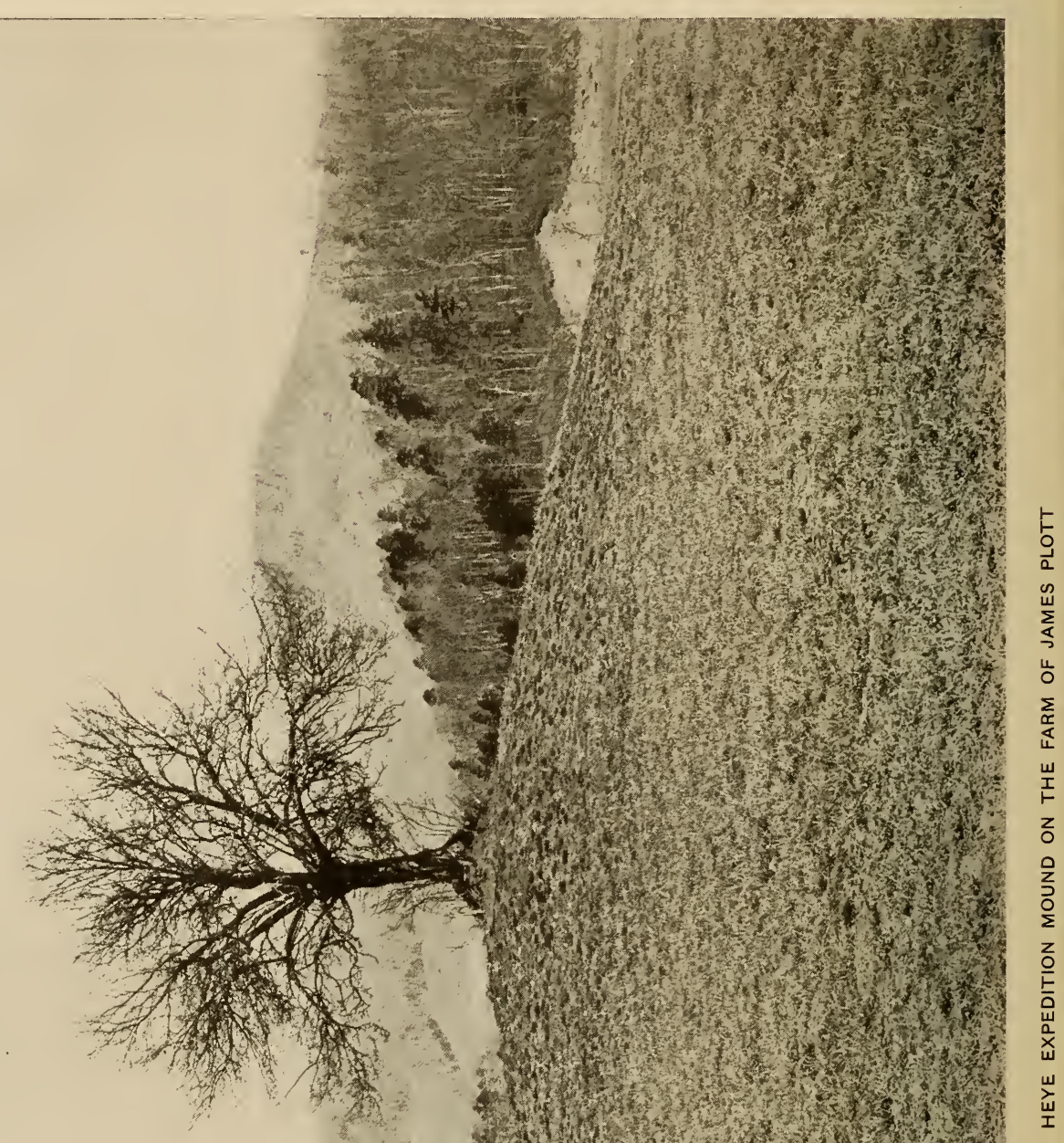

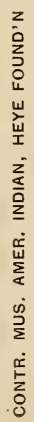

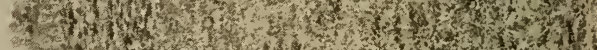

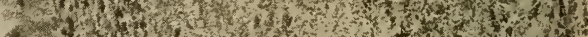

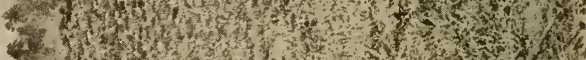

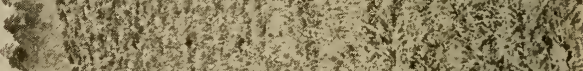

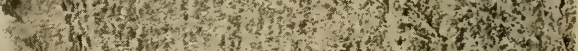

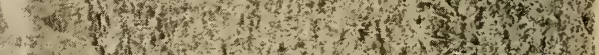

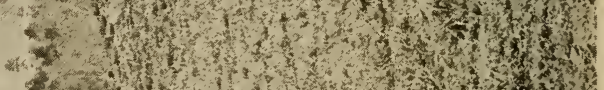
4.

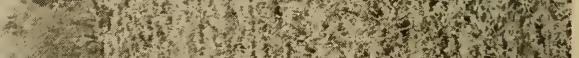

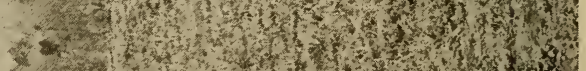

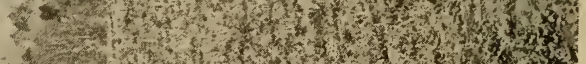

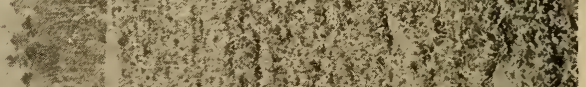

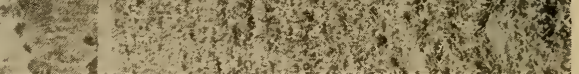




\section{CERTAIN MOUNDS IN HAYWOOD COUNTY, NORTH CAROLINA}

BY

\section{GEORGE G. HEYE}

$\mathrm{E}$

XPLORATION of the mounds herein considered was undertaken by the writer in the spring of I9I5, in the interest of the Museum of the American Indian, Heye Foundation, of New York City.

The two mounds first examined are situated on the farms of James and Richard Plott, two miles southwest of Canton, Haywood county, North Carolina, and a short distance from the junction of the forks of Pigeon river. Originally a third mound was situated practically on the bank of Pigeon river, three hundred yards northwestward from the "Heye Expedition mound." (See fig. I.)

The mound last mentioned was the one excavated by our expedition; it is on the farm of James Plott and has an apple tree upon it (pl. I). The second mound referred to, on the farm of Richard Plott, also has an apple tree growing from its summit.

The third mound, that marked "previously worked" (fig. I), was explored in I 880 by Mr Mann S. Valentine for the Valentine Museum of Richmond, Virginia. The only remaining evidence of the existence of this mound is a slight elevation. The situation of the earthwork in its relation to the others is shown on the accompanying sketch-map.

Near these mounds, and extending along the bank of the river for a distance of more than a quarter of a mile, is a stretch of ground the surface of which is six feet below the elevation of the land from which the mound rises, and which, owing to its sheltered position, would have been an ideal site for a camp. This plain is now flooded during spring freshets, and its earth is intermixed with sand, but every season many potsherds and stone implements are uncovered 
by the plow. The surface from the ridge of the mound to this low land is covered thickly with similar fragmentary artifacts.

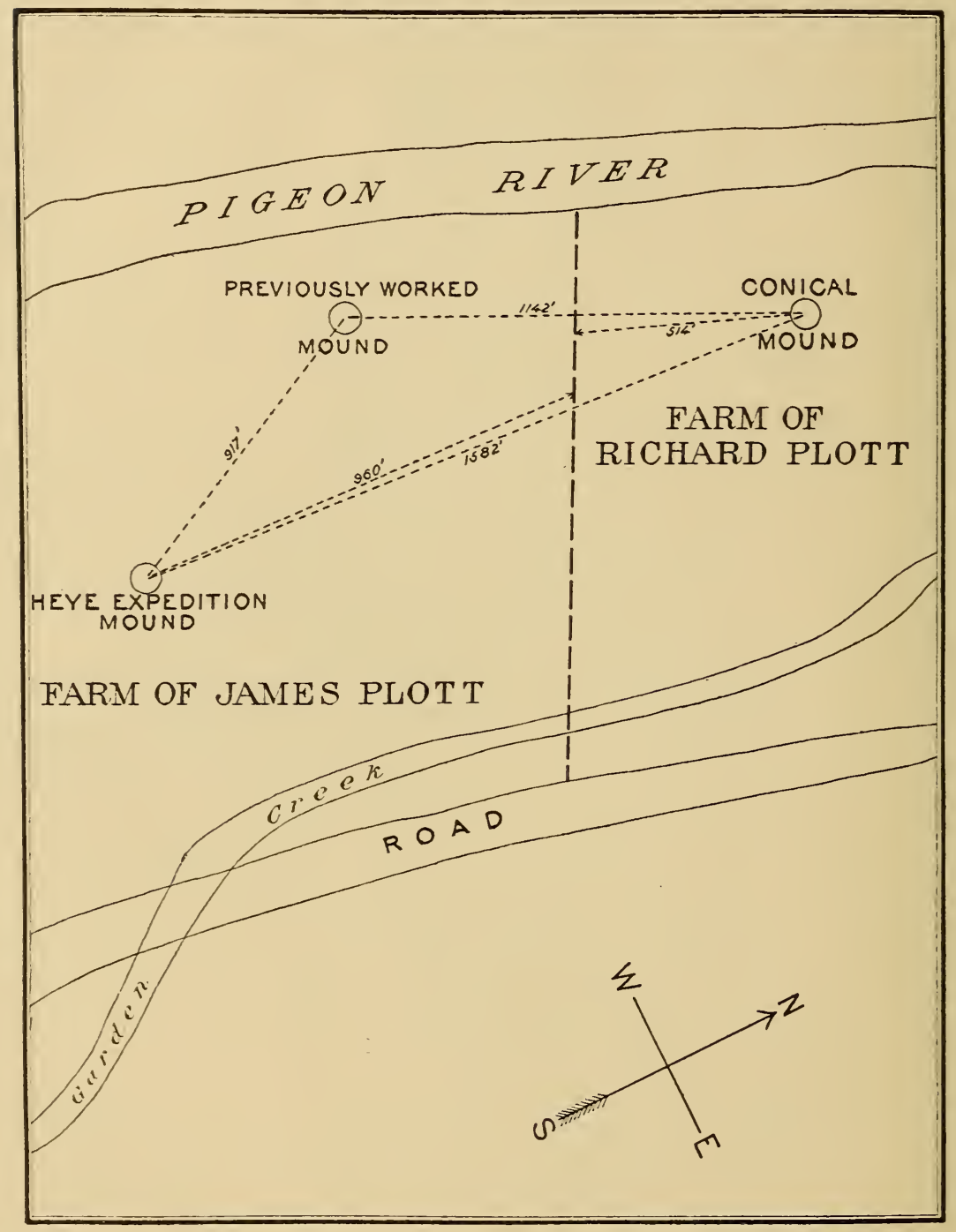

FIG. I,-Map Showing the Location of the Mounds near Pigeon River, North Carolina. 


\section{The Richard Plott Mound}

The Richard Plott mound is conical in form and averages eighty feet in diameter by eighteen feet in height. On the sloping side of the mound many potsherds and broken chunkee stones of quartz were found. As before mentioned, in the center of the mound grows an old apple tree. Fifteen feet west of it lay the remains of a burial, consisting of many human bones and a shell bead that had been exposed by plowing. On the same site, but nearer the base of the mound, a deposit of charred acorns and nuts was discovered, and in several places masses of charcoal were seen. This superficial examination was made during a preliminary survey of the valley, when the presence of growing crops made excavation impracticable. During our sojourn the owner of this mound informed us that several human skeletons had been unearthed in plowing its surface.

\section{The James Plott Mound}

The James Plott mound is of the conical type; it averaged sixty feet in diameter and was thirteen feet in height. On the crest stood the old apple tree, above referred to, thirty inches in diameter at the base. The roots still held the earth in place, and thereby preserved to some extent the height of the mound when the tree was planted. The difference between this point and the present general summit of the mound is about two feet (pl. I).

The work of excavation was commenced on the southwestern side, at a point forty-five feet from the center of the mound. Twelve inches below the surface a mass of stones was found, the uppermost of which were small river pebbles, but among them and underneath were heavy slabs which evidently came from the cliffs on the opposite side of Pigeon river. The owner of the mound stated that originally similar stones surrounded the base of the mound, but that he had removed many wagonloads of them. In a stratum of earth beneath this layer of stones many potsherds were found. This stratum averaged a foot in thickness and beneath it was undisturbed soil. Above the stones was a layer of black loam that evidently had been brought from the flats near the river, because no earth similar to it is found in the immediate vicinity. Six and 
one-half feet from the point where the layer of stones was first encountered the vertical section of a trench put down from the surface showed the stratification illustrated in plate II, $a$. Further excavation revealed the fact that the layer of stones commenced to dip in the center, and as the earth was removed toward that point this tendency became more pronounced until the center of the mound was reached. The stratification here is shown in plate II, $b$. After passing the center of the mound, the stratum of stones in the second half was found to be similar to that of the first half, and gradually flattened out to the opposite margin of the mound where it became straight. At no place there did the stone layer extend more than two feet below the surface of the mound, hence it was shown that when the mound was built, yellow sand and earth from the surrounding fields were piled in a circle, then covered with the stones, then in turn piled with the black loam.

On the base of the mound, slightly within the beginning of the stone layer, were artificial depressions that had been used as firepits. Seventeen of these were found, the largest of which was one foot in diameter and the smallest three inches, while their depth below the base ranged from four inches to two feet six inches. A table of these, with their contents, follows:

Pits in the Floor of the Mound

\begin{tabular}{|c|c|c|c|}
\hline No. & Diameter & Depth & Materials Contained \\
\hline I & I $2^{\prime \prime}$ & $I^{\prime}$ & Charcoal, mica; slab of mica on top. \\
\hline 2 & IO & $7^{\prime \prime}$ & Charcoal. \\
\hline 3 & $10^{\prime \prime}$ & $4^{\prime \prime}$ & $\begin{array}{l}\text { Charcoal and carbonized twigs, resting on which was a } \\
\text { slab of mica, and in the mass a rough, unworked stone, } \\
\text { a small irregular piece of burnt clay, and fragments } \\
\text { of burnt bone. }\end{array}$ \\
\hline 4 & $3^{\prime \prime}$ & $4^{\prime \prime}$ & Charcoal; mica on top. \\
\hline 5 & $8^{\prime \prime}$ & $I^{\prime} \quad 3^{\prime \prime}$ & Charcoal; four small pieces of mica. \\
\hline 6 & $71 / 2^{\prime \prime}$ & $2^{\prime} 6^{\prime \prime}$ & $\begin{array}{l}\text { Filled with discolored earth and small pieces of charcoal, } \\
\text { burnt deer-bone, potsherds, small pieces of flint. }\end{array}$ \\
\hline 7 & $9^{\prime \prime}$ & $I^{\prime} I^{\prime \prime}$ & Discolored earth and charcoal. \\
\hline 8 & $6^{\prime \prime}$ & $I^{\prime} \quad 3^{\prime \prime}$ & $\begin{array}{l}\text { Filled with mixed earth and charcoal, with a piece of } \\
\text { mica on top. }\end{array}$ \\
\hline 9 & $9^{\prime \prime}$ & $I^{\prime} \quad 3^{\prime \prime}$ & Filled with mixed earth; charcoal. \\
\hline Io & IO" & $\mathrm{I}^{\prime} 8^{\prime \prime}$ & $\begin{array}{l}\text { Filled with earth and charcoal containing animal bones } \\
\text { and potsherd. }\end{array}$ \\
\hline II & I9" & $I^{\prime} 9^{\prime \prime}$ & $\begin{array}{l}\text { Charcoal and earth mixed, and pieces of bone; large } \\
\text { pieces of charcoal and small piece of mica on top. }\end{array}$ \\
\hline I 2 & $6^{\prime \prime}$ & $2^{\prime} \quad \mathrm{I}^{\prime \prime}$ & Ashes, burnt deer-bones, mica, potsherd, charcoal. \\
\hline 13 & $5 \frac{1}{2} 2^{\prime \prime}$ & $I^{\prime} I^{\prime \prime}$ & Mica, charcoal, and burnt animal bones. \\
\hline I4 & $7^{\prime \prime}$ & $\mathrm{I}^{\prime} \quad 3^{\prime \prime}$ & Charcoal, potsherds, burnt animal bones. \\
\hline I 5 & $6^{\prime \prime}$ & $I^{\prime} \quad 4^{\prime \prime}$ & Charcoal, potsherds, burnt animal bones. \\
\hline I6 & $6^{\prime \prime}$ & $I^{\prime} \quad 3^{\prime \prime}$ & Charcoal, potsherds, mica. \\
\hline I7 & $7^{\prime \prime}$ & $I^{\prime} 7^{\prime \prime}$ & Charcoal. \\
\hline
\end{tabular}




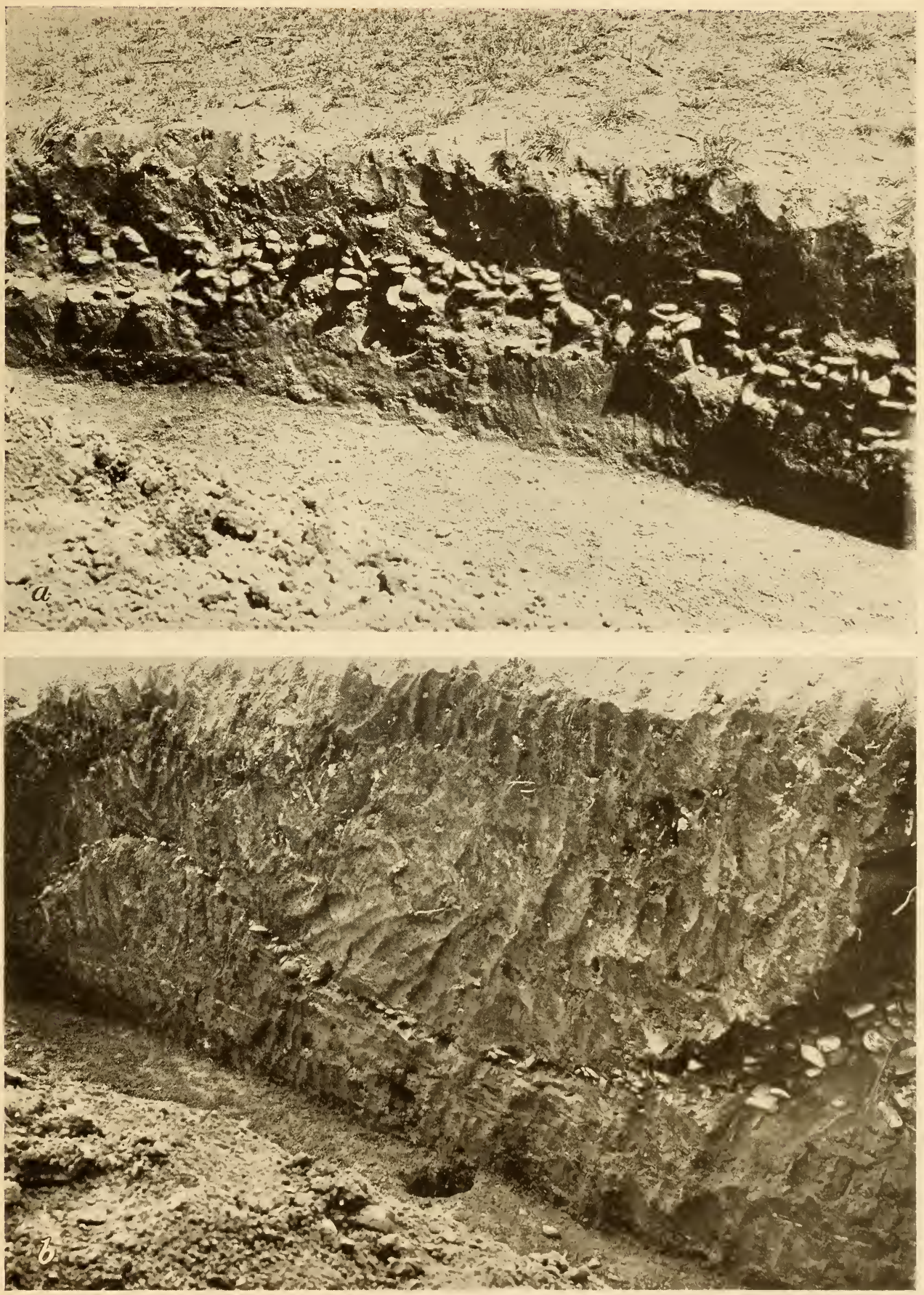

A. SECTION OF THE HEYE EXPEDITION MOUND, SHOWING STRATIFICATION

B. STRATUM OF STONES NEAR THE CENTER OF THE HEYE EXPEDITION MOUND 

Parts of seven human skeletons were found in the mound, all of them in a very fragmentary condition.

The first evidence of a skeleton was the tibia of a child, found three inches below the surface, where it had been turned up by the plow. The other bones of this skeleton were not found.

The next indication of human remains was part of a lower jaw, found near the surface, one of the condyles protruding from the soil. It was impossible to determine where the burial had been, as this fragment, like the one just mentioned, had been carried from its original position by the plow. James Plott, the owner of the mound, stated that he had not noticed human bones in his plowing, but there is no doubt that, owing to cultivation and to natural causes, the surface of the mound has been greatly reduced and that many burials have been upturned and the bones scattered.

Directly west of the center of the mound a stone grave was found, one of the upright stones of which protruded slightly above the surface (pl. III). The grave measured six feet eleven inches in length by three feet three inches in width. It was directed north and south, the rounded or head end being toward the latter point. The stones forming the sides of the grave were roughly shaped, the ends that extended downward into the ground being tapered. The sides and northern end of the grave were so placed that the stones touched, while those forming the semicircle at the head were set slightly apart.' The bottom, or floor, was formed of two layers of large flat water-worn stones. In the lower layer, near the center of the grave, a large thick potsherd was found, and near it a piece of mica.

The stones that covered the grave had been placed on the earth which filled it, and did not rest on the upright side or end stones. The stones that lined the bottom of the grave rested on a stratum of yellow river sand.

The only part of a skeleton found in this grave was a fragment of skull. Three feet east of the grave the femora were found, but no other parts of the burial were visible. Aside from the potsherd and the piece of mica already mentioned, nothing was found with the remains. From the condition of the grave, and because the 
leg-bones were found beyond its limits, it is probable that this interment had been opened either by early settlers in the region or had been despoiled by the Cherokee or by other Indians who occupied the region after the departure of the original inhabitants.

The fourth burial was represented by a fragment of the skull of an adult, found seren feet beneath the surface. Not far from this fragment another was found, resting at about the same level, and beneath it was a layer of water-worn pebbles. Near the second fragment of cranium a portion of the pelvis and particles of the femora were found. No other bones were in-evidence, and those mentioned were greatly decayed. The general direction of the disturbed earth was east and west, which was probably the trend of the grave, in which case the head was directed toward the west. Near the lower part of the left femur a lignite celt was found; it is in perfect condition and the blade-end is sharp. This implement measures five-eighths of an inch in thickness by one and seveneighths in width at the blunt end, and three inches at the blade end; its greatest length is four and a quarter inches. The poll-end shows the process of manufacture by rubbing similar to that exhibited by some of the jadeite celts from Alaska. Nothing else was found with this burial.

The fifth burial found was represented by a fragmentary skull, a portion of the lower jaw, and parts of the upper cervical vertebræ. This skeleton, which was that of an adolescent, lay eighteen inches beneath the surface. Nothing was found with it. Not far from these bones were two leg-bones, in fragments, resting at about the same depth and probably belonging to the same skeleton.

The next burial, consisting of the arm and leg-bones, portions of the pelvis, and a few other fragments, was found one foot beneath the surface. From the massed condition of these bones it was evident that this burial was of the "bundle" type.

The seventh burial found was that of a child, the only remaining portions of which were fragments of the skull, which lay eighteen inches below the surface. Accompanying this burial were an arrowpoint and a piece of mica.

Besides the above skeletal remains a few scattered fragments of human bones were found during the excavation. 


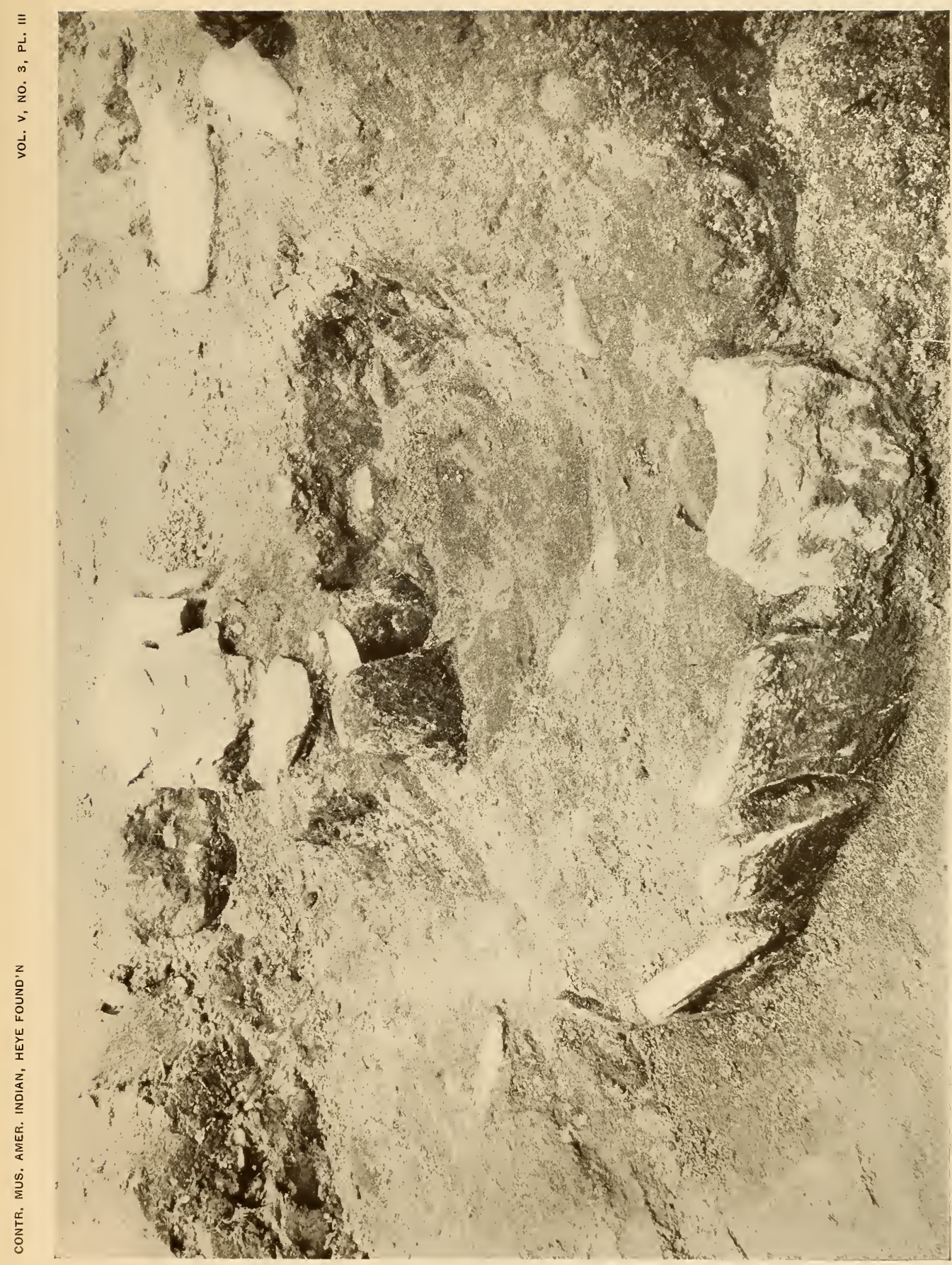



After removing the apple tree from the center of the mound, in and under the roots extending to a depth of about two feet was a stratum of river sand. Six inches below this sand deposit were two large sheets of mica, each about three-eighths of an inch in thickness, which rested upon a circular disc of bitumen four inches in diameter by an inch and a half in thickness. Beneath this bitumen object were three layers consisting respectively of red ochre, white clay, and yellow ochre. These layers, each averaging an inch in thickness, extended entirely across the pit, which was twelve inches in diameter. Next in order in the pit were burnt bones and ashes, among which were found two potsherds and two fossil shark's teeth showing artificial working at the edge. The pit was about ten inches deep, and at its bottom was a flint nodule weighing about thirty pounds, a material not known to any of the neighboring land-owners as occurring in situ in this section.

During the remaining excavation of the mound comparatively few potsherds were found; these are all small and show only incised decoration. Several short, knob-like legs of jars show that the pottery is of Cherokee ware. There are also several bottoms of jars, of the pointed type, but with the exception of nineteen arrowpoints and a crude hammerstone, no implements were found.

As all the burials were found near the surface and on the upper side of the stratum of stone, it is evident that they were intrusive and that the mound was not designed for mortuary purposes. It is therefore possible that it was used by the Cherokee in playing their ball game. The situation of the two mounds indicates that they could have been used to mark the limits of the ball-field or to have been used otherwise in connection with the game of ball.

\section{Mooney ${ }^{1}$ says:}

Kănúga-An ancient Cherokee town on Pigeon river, in the present Haywood county, North Carolina. It was deserted before the beginning of the historic period, but may have been located about the junction of the two forks of Pigeon river, a few miles east of Vaynesville, where there are still a number of mounds and ancient cemeteries extending for some miles down the stream. Being a frontier town, it was probably

${ }^{1}$ Ja mes Mooney, Myths of the Cherokee, Nineteenth Ann. Rep. Bur. Amer. Ethnol., p. 479 . 
abandoned early on account of its exposed position. The name, signifying "scratcher," is applied to a comb, used for scratching the ball-

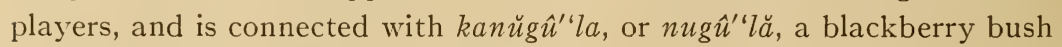
or brier.

\section{The Second James Plott Mound}

The second mound on the James Plott farm is now a low, elongated knoll. As above stated, this mound was explored and partly leveled by members of the Valentine Museum expedition in I880. According to old residents who were familiar with the mound before it was disturbed, it was similar in size and shape to the others of this group, except that the top was more flattened.

\section{Singleton Mound}

Between Canton and Waynesville, about two miles southwest of the Plott mounds, on the property of Mr T. D. Singleton, at Bethel, Pigeon township, Haywood county, was a small, low, circular mound. This mound averaged twenty feet in diameter and from a foot to two feet above the general surface. Being situated in Mr Singleton's front dooryard, it had been used as a flower-bed. At one time two large trees stood on the mound, but they were removed by the present owner of the place, who informed us that they were between sixty to eighty years old.

The work of excavation was commenced on the roadside of the earthwork. In the southern part several potsherds and a pitted hammerstone were found, and in the center an earthenware jar, which stood upright but was somewhat crushed, although the base and portions of the side were in place. This vessel is of the pointedbottom type and has two crude nodes projecting from the rim for handles (pl. IV). The decoration is of the incised and punctate type, and consists of three panels, in each of which is an ornamental figure. The diameter of the jar at the mouth is $5 \frac{1}{4}$ inches, the maximum width is $61 / 2$ inches, and its height $81 / 4$ inches. Nothing else was found in the mound.

The Singleton mound was composed of earth and showed no stratification. Particles of charcoal were scattered here and there but there were no charcoal deposits such as were found in the Plott 


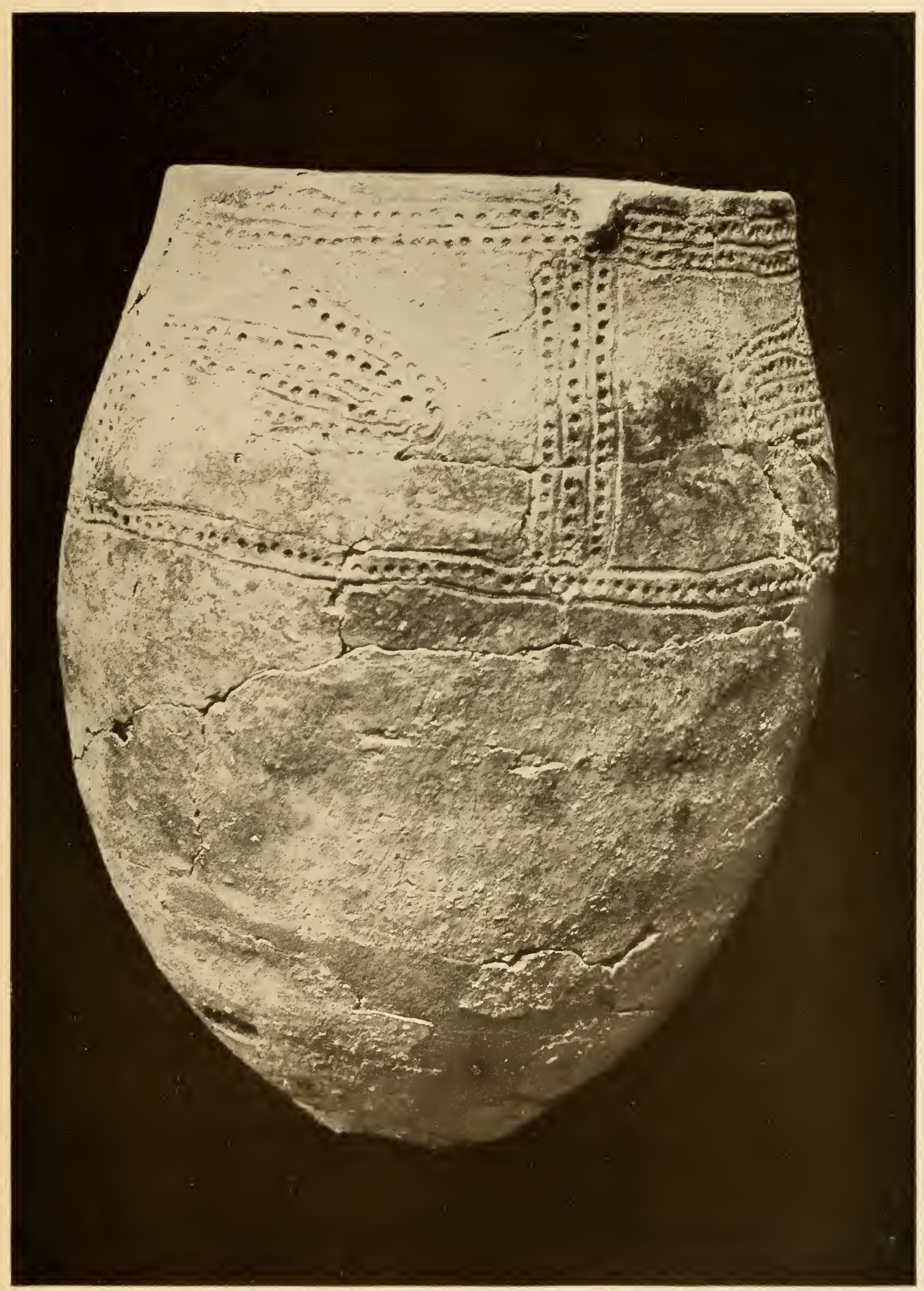

POTTERY VESSEL FROM THE SINGLETON MOUND 

mound. The mound earth extended to the natural clay surface which was four feet below the summit of the earthwork at the center.

\section{Scattered Artifacts}

During the writer's sojourn in Haywood county he was fortunate enough to collect a number of artifacts that had been found on the surface, including a variety of steatite ornaments, most of which are drilled for suspension. Steatite pipes were seemingly numerous and range from the small trade-pipe form to the large and massive L-shaped variety ornamented with carving.

Celts were not common in this neighborhood, and only one grooved ax was obtained. A large number of small discs of steatite and other stone were collected, but comparatively few arrowpoints were gathered. 



\section{5:}

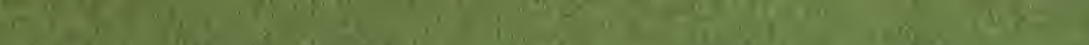

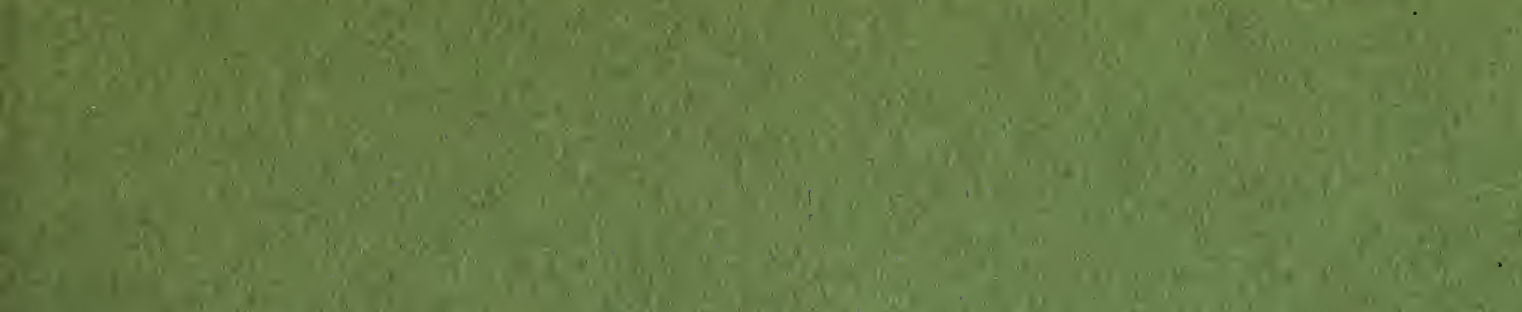

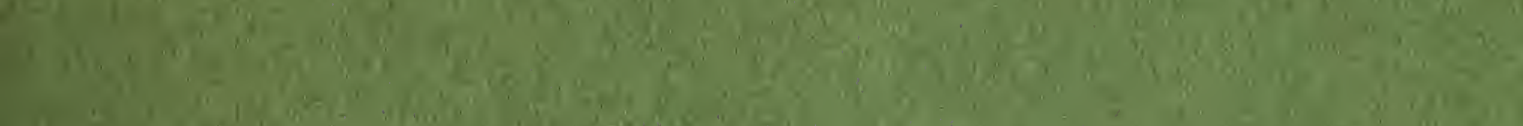

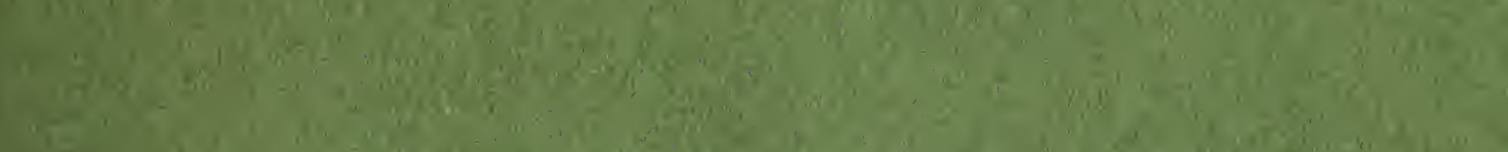

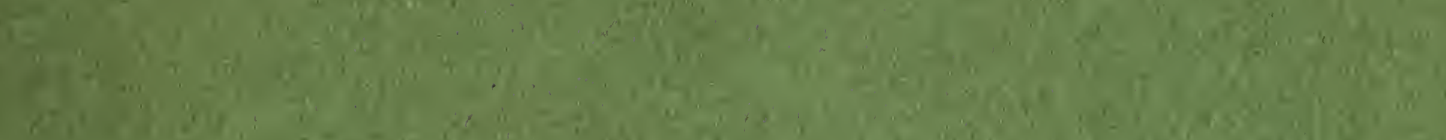

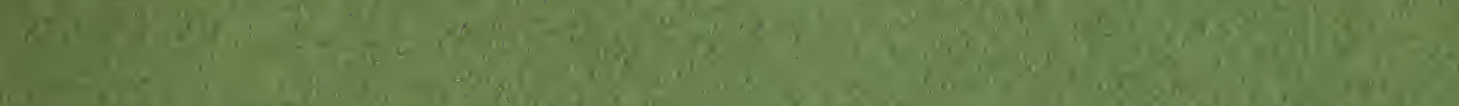

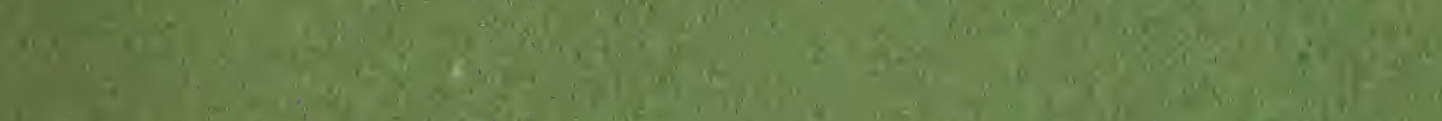

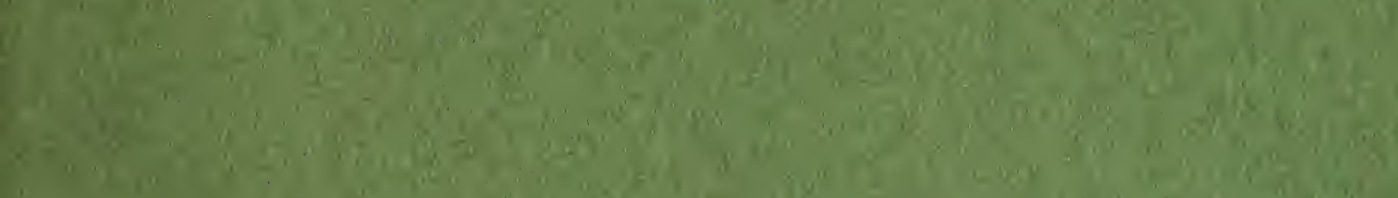
$\sin ^{2}+2$

W.

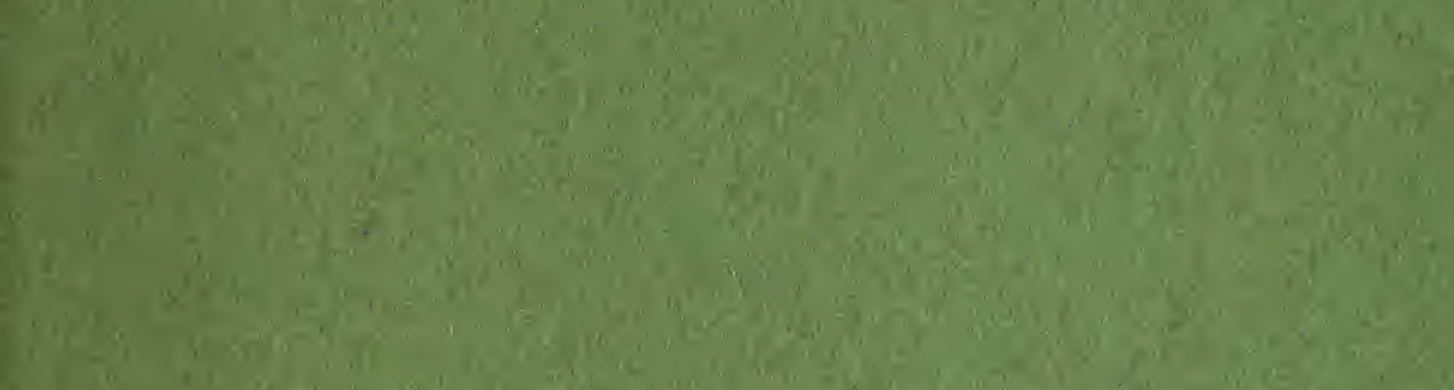

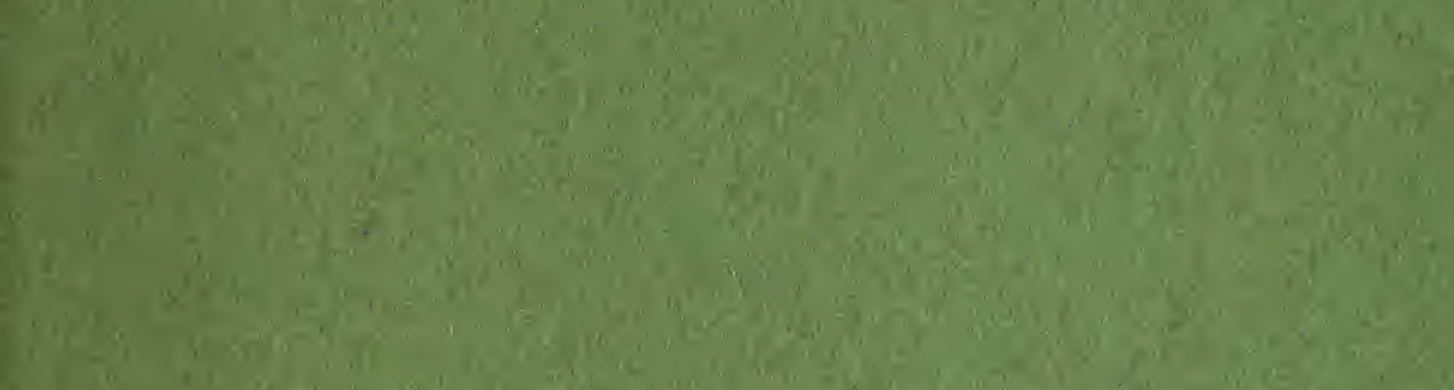
E.

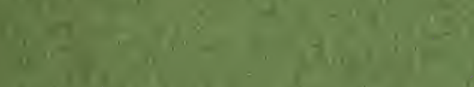

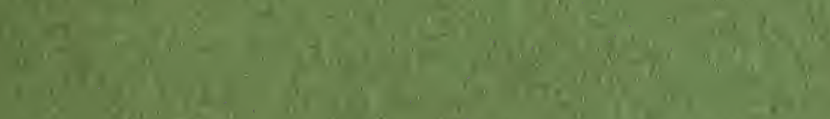

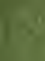

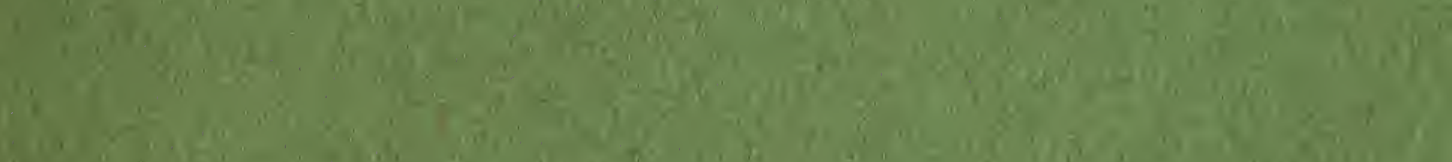

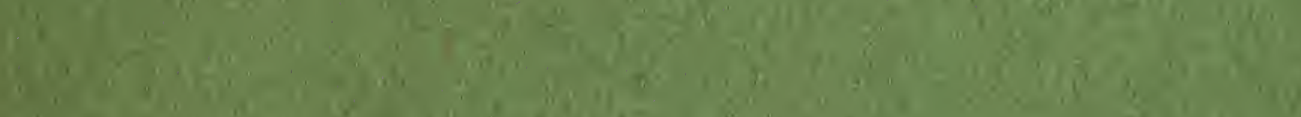

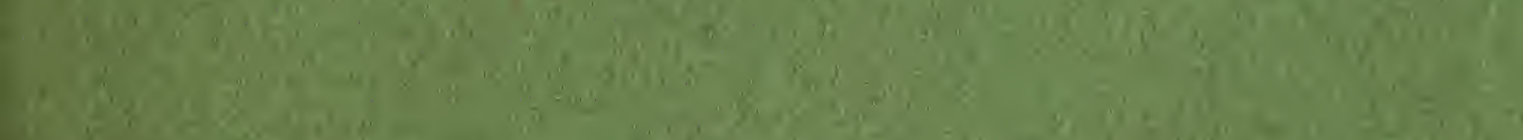

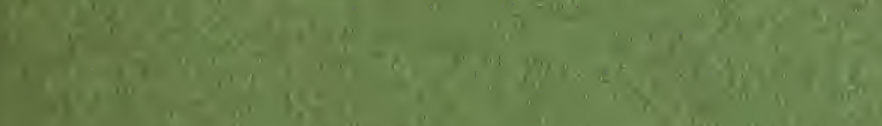
is

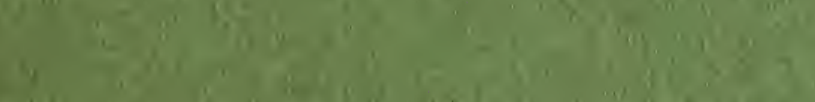
s.

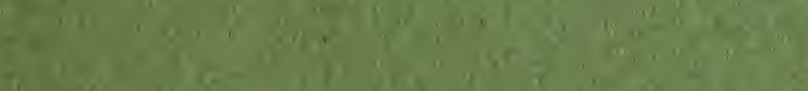

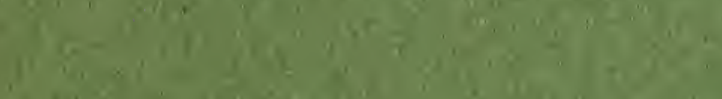

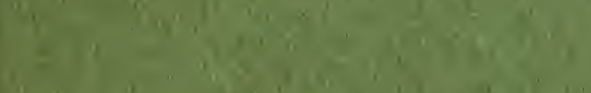

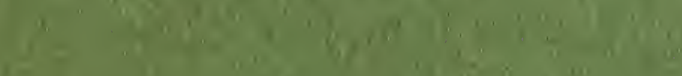
Whe m. e-61 


